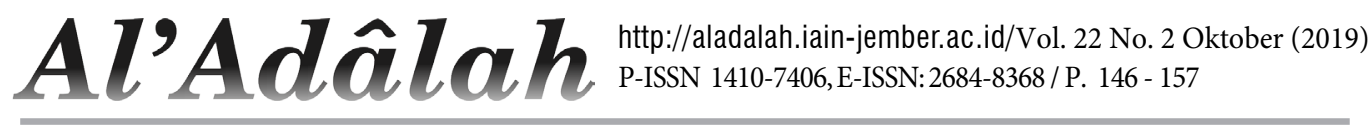

\section{Kitab Kuning Dan Konstruk Nalar Pesantren}

\author{
Muhammad Ardiansyah \\ Institut Agama Islam Negeri (IAIN) Jember \\ ardonkuye@yahoo.com
}

\begin{abstract}
Abstrak:
Berbagai tantangan yang dihadapi pesantren, khususnya terkait dengan pengembangan kajian keilmuan dalam rangka menjawab persoalan-persoalan kontemporer umat Islam di Indonesia. Isu HAM, Gender, dan dan nasionalisme, misalnya, menjadi tantang besar bagi kalangan pesantren untuk menjawab dan emmcahkan problem kebangsaan tersebut. Namun, jika pesantren hanya mengandalkan literatur kitab klasik apalagi dengan metodologi pengkajian yang bersifat tradisional sebagaimana yang selama ini dikembangkan, maka persoalan-persoalan di atas tidak terjawab dengan baik. Kajian keilmuan di pesantren harus lebih memberikan porsi besar bagi pengembangan kajian keislaman dengan corak burhani. Demokrasi hanya bisa tegak dengan berlakunya supremasi hukum. Hukum memiliki logika dan rasionalitas-nya, yang itu bisa dikembangkan dengan mengkaji lebih banyak ushul fiqh dan manthiq. Dengan mensinergiskan tiga nalar, bayani, burhani, dan irfani, pesantren akan mampu menghadapi tuntutan zaman. Untuk itu, pesantren perlu merumuskan kurikulum kajian keislaman secara lebih serius dan sistematis dengan memepertimbangkan porsi masing-masing nalar tersebut.
\end{abstract}

Kata kunci: kitab, kuning, dan pesantren

\section{Abstract:}

The various challenges faced by pesantren, especially those related to the development of scientific studies in the context of answering contemporary problems of Muslims in Indonesia. The issues of human rights (HAM), gender, and nationalism, for example, are a big challenge for pesantren to answer and solve this national problem. However, if the pesantren only relies on classical literature, let alone the traditional methodology of study as it has been developed, then the above problems will not be answered properly. Scientific studies in Islamic boarding schools should provide a greater portion for the development of Islamic studies with a burhani style. Democracy can only be upheld by the enactment of the rule of law. Law has its logic and rationality, which can be developed by studying more ushul fiqh and manthiq. By synergizing the three reasons, bayani, burbani, and irfani, pesantren will be able to face the demands of the times. For this reason, Islamic boarding schools need to formulate a more serious and systematic curriculum for Islamic studies by considering the respective portions of reasoning.

Key words: book, yellow, and pesantren

\section{Latar belakang}

Pesantren, konon, menjadi benteng tradisi Islam Nusantara. Geneaologi keilmuan dan jaringan kekerabatan kiai menjadi kekuatan sekaligus ciri khas pesantren. Salah satu komponen terpenting pesantren adalah literatur kitab klasik (baca: kitab kuning), khususnya karya-karya ulama syafi'iyah. Pengajaran kitab-kitab klasik, atau yang populer dengan nama kitab kuning, 
merupakan satu-satunya pengajaran formal di pesantren. ${ }^{1}$ Tujuan utama pengajaran ini untuk mencetak kader-kader ulama yang mampu menjawab berbagai persoalan sosial keagamaan ketika kelak terjun ke masyarakat.

Pesantren membangun suatu konstruk khasanah pengetahuan yang khas, konstruk pengetahuan yang kemudian menjadi karakter keilmuan Islam Nusantara. Kitab Kuning sebagai inti tradisi keilmuan pesantren tidaklah mandeg, tetapi justru berdialektika dengan konteks sosiohistoris masyarakakat sekitar pesantren. Dengan demikian, pesantren tidak saja menjadi bagian dafri tradisi intelektual Timur Tengah, namun juga berhasil memunculkan karakteristik keilmuan yang khas Nusantara.

Pengajaran kitab kuning juga menjamin kelestarian khasanah intelektual Islam. Melalui pesantren, puluhan, bahkan ratusan kitab kuning dipelajari sebagai salah satu sumber pengetahuan keagamaan. Kitab-kitab tafsir, hadis, fiqh, tasawuf, dan ilmu-ilmu lain hampir tak mungkin dikaji secara mendalam di luar pesantren. Santri belajar etika, fiqh, tauhid, tafsir, dan tentu saja ilmu alat. Sekedar contoh, mereka mengaji Ta'lim al-Muta'allim, Fathul al-Qarib, Qathru al-Ghaits, Jalalain, al-Ajurumiah, juga Ibnu 'Aqil.

Keberadaan dan pengajaran kitab kuning, dengan demikian, menjadi faktor kunci keberlangsungan dan kelestarian tradisi intelektual pesantren. Kitab kuning merupakan salah satu elemen kunci, selain kyai, yang membentuk tradisi intelektual pesantren. Kitab kuning menjadi penting mengingat alasan utama munculnya pesantren adalah untuk mentransmisikan Islam tradisional melalui pengajaran kitab-kitab klasik yang ditulis berabad-abad yang lalu.

Meskipun struktur dasar bangunan intelektual pesantren tidak atau belum mengalami perubahan yang mendasar, namun secara perlahan dan melalui tahap-tahap yang tidak mudah diamati, terjadi berbagai pergeseran intelektual di pesantren. Sudah sejak hadirnya sistem madrasah (diniyyah) di lingkungan pesantren sejak permulaan abad ke20, tradisi "santri kelana"2 yang menjadi salah satu ciri penting tradisi intelektual pesantren berangsur-angsur mulai hilang. Sistem kelas yang bertingkat-tingkat dan ketergantungan pada ijazah-ijazah formal menyebabkan santri harus menetap untuk beberapa waktu di satu pesantren saja.

1 Zamakhsyari Dhofier, Tradisi Pesantren: Studi tentang Pandangan Hidup Kyai (Jakarta: LP3ES, 1982), hlm. 50.

2 "Santri kelana" adalah sebutan untuk santri yang menimba ilmu-ilmu agama dengan berkelana dari satu pesantren ke pesantren yang lain. Hal ini terutama dimaksudkan untuk menambah luas wawasan dan pengetahuan keagamaan selain upaya untuk mendapatkan "barokah" dari berbagai kiai. 
Dengan semakin banyaknya pesantren dewasa ini, khususnya yang berhaluan Islam tradisional, ${ }^{3}$ bukan berarti semakin meningkatnya kualitas keilmuan di pesantren. Meski dengan hadirnya Ma'bad 'Aly di beberapa pesantren besar (pesantren luhur) kualitas kajian kitab kuning semakin intensif dan mendalam, namun secara umum kajian kitab di pesantren-pesantren tradisional mengalami kemerosotan. Hal ini diantaranya disebabkan semakin pendeknya masa studi santri di pesantren sehingga tidak cukup waktu untuk mengkaji kitab-kitab "besar". Dibukanya sekolah-sekolah formal di pesantren juga mengakibatkan kecenderungan lebih mementingkan ilmu-ilmu umum ketimbang ilmu-ilmu agama, sehingga minat untuk mengkaji kitab-kitab kuning pun menurun. Selain itu, kebanyakan pesantren yang baru didirikan belakangan lebih berorientasi pada pengajaran teks-teks sederhana (pesantren dasar) dan menengah (pesantren madya). ${ }^{4}$

Semua itu mengakibatkan kecenderungan semakin menurunnya kualitas kajian dan pemahaman santri terhadap kitab kuning. Kondisi ini menimbulkan kekhawatiran bahwa pesantren sebagai penjaga tradisi intelektual Islam tradisional akan semakin kehilangan kekuatannya dalam diskursus intelektual Islam di negeri ini. Bahkan banyak kitab yang kini "hilang" dari peredaran, karena sudah tidak atau jarang dikaji di pesantren.

\section{Pesantren dan Kitab Kuning}

Pesantren merupakan salah satu jenis pendidikan di Indonesia yang bersifat tradisional untuk mendalami agama Islam dan mengamalkanya sebagai pedoman hidup keseharian. Salah satu fungsi pesantren yang sampai saat ini masih belum pernah berubah adalah fungsi pesantren sebagai insitusi keilmuan, dimana kitab kuning merupakan referensi utama dalam proses belajar mengajar. Masyarakat pesantren sangat meyakini akan kandungan kitab kuning dan bahkan menjadikannya sebagai pandangan hidup, maka nalar yang ada dalam kitab kuning tersebut juga ikut berperan penting didalamnya. Oleh karena itu salah satu masalah yang berkaitan dengan pesantren yang menarik perhatian adalah bagaimana nalar literatur-literatur (kitab kuning) tersebut.

\footnotetext{
3 Islam tradisional, sebagaimana dikemukakan Zamaksyari Dofier, adalah "Islam yang kuta terikat dengan dasardasar pikira Islam yang dikembangkan oleh ulama dari abad ke 7 sampai dengan abad 13". Kandungan intelektual Islam tradisional berkisar pada paham akida Abu Hasan al-Asy'ari (khususnya melalui karya-karya Al-Sanusi) dan Abu Mansur al-Maturidi, mazhab fiqih Imam Syafi'i (kadang juga merujuk tiga imam mazab lainnya, serta ajaran-ajaran akhlak dan tasawuf Imam al-Ghazali dan Imam Abu Qosim al-Junaidi. Lihat Zamaksyari Dofier, "Tradisi Pesantren: Suatu Studi tentang Peranan Kiyai dalam Memelihara dan Mengembangkan Ideologi Islam Tradisional”, dalam Prisma, No. 2 Februari 1981, hlm. 87; lihat juga Zamakhsyari Dhofier, Tradisi Pesantren..., khususnya bab VI.

${ }^{4}$ Untuk klasifikasi pesantren dasar, pesantren madya, pesantren luhur ini lihat Zamaksyari Dofier, Ibid.
} 
Pesantren sebagai lembaga pendidikan mempunyai watak utama, yaitu sebagai lembaga pendidikan yang memiliki ciri-ciri khas. Karena, pesantren memiliki tradisi keilmuan yang berbeda dengan tradisi keilmuan lembaga-lembaga pendidikan lainnya, seperti madrasah atau sekolah. ${ }^{5}$ Salah satu ciri utama pesantren sebagai pembeda dengan lembaga pendidikan lain, adalah pengajaran kitab kuning, kitab-kitab Islam klasik yang ditulis dalam bahasa Arab baik yang ditulis oleh para tokoh muslim Arab maupun para pemikir muslim Indonesia. ${ }^{6}$

Dengan demikian, selama ini ranah epistemologi atau struktur keilmuan Islam pesantren bisa dikatakan belum mendapatkan perhatian khusus dari para ilmuan muslim. Yang ada hanya sebatas keterkaitan antara struktur keilmuan dengan kurikulum atau kitab kuning atau hanya sekedar menyebutkan dan mengungkapkan isinya secara global, tidak sampai pada struktur nalar keilmuan kitab kuning yang paling fundamental.

Muhammad Abed Al-Jabiri, pemikir asal Maroko, sangat brilian ketika berbicara tentang nalar. Ia mengemukakan bahwa dalam islamic studies paling tidak ada tiga nalar yang menjadi ciri khasnya, yaitu nalar bayani, irfani dan burhani. Penelitian ini menggunakan kerangka teoretik strukturalisme, dalam hal ini pemetaan nalar keilmuan bayâni, 'irfâni dan burhâni yang telah digagas oleh al-Jabiri untuk membongkar struktur keilmuan pesantren.

\section{Metode Penelitian}

Penelitian ini adalah penelitian kepustakaan (library research) sehingga jenis penelitian ini adalah kualitatif. Penelitian ini dilakukan melalui beberapa metode. Pertama, metode deskripsi, adalah pemaparan yang sistematis, faktual, dan akurat mengenai kitab kuning dengan cara deduksi maupun induksi. Kedua, metode interpretasi, di mana penulis menyelami isi buku dan sedapat mungkin menangkap arti dan makna yang dimaksud. Observasi dan wawancara diperlukan untuk menggali data mengenai metode kajian kitab kuning dan cara pandang pesantren (kiai-santri) terkait dengan isu-isu kontemporer.

Langkah-langkah penelitian pertama-tama adalah menginvenrisasi kitab-kitab kuning yang diajarkan di pesantren di Jember. Metode yang digunakan adalah dokumentasi sekaligus melakukan wawancara dengan kiai atau ustaz pesantren terkait pengajaran kitab kuning di pesantrennya. Langkah selanjutnya adalah mendeskripsikan kitab-kitab yang tersebut dan

5 Abdurrahman Wahid, Menggerakkan Tradisi: Esai-esai Pesantren, (Yogyakarta: LKiS, 2001), hlm. 157.

${ }^{6}$ Pengertian kitab kuning seperti ini sengaja penulis melakukan mengingat realitas di pesantren, bahwa kitabkitab yang diajarakan di pesantren itu meliputi karya-karya pemikir muslim Indonesia, seperti karya Syekh Nawawi Banten. 
AL-ADALAH, Vol. 19 No. 2, Oktober 2019

mengalisisnya dengan membenturkan dengan persoalan-persoalan kontemporer. Ini dimaksudkan untuk mengyukur sejauh mana kajian kitab kuning di pesantren mampu menjawab problematika persoalan umat kontemporer.

\section{Kitab Kuning Dan Konstruk Nalar Pesantren}

Pesantren merupakan lembaga pendidikan Islam non formal yang masih melestarikan tradisi dan ajaran ulama masa lalu, khususnya ulama klasik dari abad VII-XIII M. Tradisi tersebut termaktub dalam literatur kitab kuning (al-kutub as-safra). Kitab kuning merupakan pesantren adalah literarur kitab klasik, khususnya karya-karya ulama syafi'iyah. Pengajaran kitab-kitab klasik, atau yang populer dengan nama kitab kuning, merupakan satu-satunya pengajaran formal di pesantren Tujuan utama pengajaran ini untuk mencetak kader-kader ulama yang mampu menjawab berbagai persoalan sosial keagamaan ketika kelak terjun ke masyarakat. ${ }^{7}$

Pengajaran kitab kuning juga menjamin kelestarian khasanah intelektual Islam. Melalui pesantren, puluhan, bahkan ratusan kitab kuning dipelajari sebagai salah satu sumber pengetahuan keagamaan. Kitab-kitab tafsir, hadis, fiqh, tasawuf, dan ilmu-ilmu lain hampir tak mungkin dikaji secara mendalam di luar pesantren. Keberadaan dan pengajaran kitab kuning, dengan demikian, menjadi faktor kunci keberlangsungan dan kelestarian tradisi intelektual pesantren.

Berdasarkan periode pengarang (mushanif), yakni sebelum atau sesudah abad ke-19 M, kitab kuning bisa dikategorikan menjadi dua: al-kutub al-qadimah, kitab klasik salaf dan al-kutub al'ashriyyah. Untuk kitab-kitab kategori pertama, semuanya merupakan produk ulama sebelum abad ke-19 M. Kitab-kitab ini memiliki karakteristik umum sebagai berikut: a) bahasa pengantar seutuhnya bahasa klasik, terdiri atas sastra liris (nadzam) atau prosa liris (natsar); b) tanpa mencantumkan tanda baca seperti koma, titik, tanda seru, tanda tanya dan sebagainya; c) tidak mengenal pembabakan alinea atau paragraf, namun disusun dengan kata kitabun, babun, fashlun, raf'un, tanbih dan tatimmatun; d) isi kandungan kitab komentar atau penjelasan dari kitab ulama sebelumnya. Karena itu, kitab sumber diperlukan sebagai matan, yang dikembangkan menjadi resume (mukhtashar atau khulashah), syarah, taqrirat, ta'qilat dan sebagainya; e) khusus kitab salaf yang beredar di lingkungan pesantren memiki keseragaman mazhab, yakni sunni, terutama mazhab arba'ah untuk literatur fiqh.

\footnotetext{
${ }^{7}$ Zamakhsyari Dhofier, Tradisi Pesantren: Studi Tentang Pandangan Kiai, cet. 6 (Jakarta: LP3ES, 1994), hlm.
} 
Kategori lainnya adalah al-kutub al-'ashriyah, kitab-kitab yang ditulis pasca abad ke-19 M. Karakteristik kitab ini adalah a) bahasanya lebih populer dan diperkaya dengan idiom-idiom keilmuan dari disiplin di luar keilmuan syar'i dan biasanya berbentuk prosa bebas, b) teknik penulisan dilengkapi dengan tanda baca, c) sistematika dan pendekatan analisisnya terpengaruh oleh perkembangan ilmu pengetahuan umum pada zamannya, d) isi kitab merupakan hasil studi literer yang merujuk pada banyak buku dan tidak terikat dengan mazhab tertentu.

Kitab kuning yang dipelajari di pesantren umumnya merupakan kitab syarh (komentar) atau hasyiyah (komentar atas komentar) atas teks yang lebih tua (matn). Kitab kuning cetakan biasanya menempatkan teks yang di-syarah-i atau di-hasyiah-i dicetak di tepi halamannya, sehingga keduanya dapat dibaca sekaligus. ${ }^{8}$

Kitab Kuning difungsikan juga oleh kalangan pesantren sebagai referensi nilai universal dalam mensikapi segala tantangan kehidupan. Ketika Kitab Kuning digunakan secara permanen, dari generasi ke generasi, sebagai sumber bacaan utama bagi masyarakat pesantren yang cukup luas, maka sebuah proses pembentukan dan pemeliharaan tradisi yang unik itu tengah berlangsung.

Yang menarik untuk diamati adalah mengapa harus Kitab Kuning yang dijadikan referensi turun temurun itu? Dan bagaimanakah pesantren memperlakukan Kitab Kuning dalam tradisi pendidikannya? Pengamatan mengenai hal ini mungkin akan mendorong kita menjawab sebuah pertanyaan fundamental: bukankah semestinya Al Qur'an dan Al Hadits yang menjadi referensi mereka?

Dari kalangan pesantren sendiri sejauh ini, sebetulnya belum ada pertanggung jawaban filosofis (argumentatif) yang utuh, dalam pengertian modern, mengenai penempatan Kitab Kuning sebagai referensi nilai-nilai universal mereka. Belakangan memang ada usaha-usaha penjelasan dari mereka, misalnya dari Abdurrahman Wahid, Ali Yafie, Masdar F. Mas'udi, Sahal Mahfudz, Tolhah Hasan, Chozin Chumaedi dan A Malik Madani lewat berbagai tulisan mereka. Namun, penjelasan mengandung unsur kritis dan evaluatif, jadi keberadaan mereka lebih dianggap mewakili penjelasan kalangan pesantren pembaharu. Terlepas dari anggapan ini, nampaknya memang masih perlu dilakukan kajian yang lebih serius untuk memahami paradigma sebenarnya yang ada di balik pemeliharaan dan pengajaran Kitab Kuning yang permanen itu.

\footnotetext{
${ }^{8}$ Martin Van Bruinessen, Kitab Kuning Pesantren dan Tarekat: Tradisi-tradisi Islam di Indonesia (Jakarta: Mizan, 1995), hal. 141
} 
AL-ADALAH, Vol. 19 No. 2, Oktober 2019

Alasan pemilihan Kitab Kuning mungkin bisa dirumuskan, antara lain, dengan mempertimbangkan perkembangan tradisi intelektual Islam Nusantara yang pernah kita bahas. Sejak periode paling dini, bersamaan dengan proses internasionalisasi - yang berarti Arabisasi dokumentasi mengenai ajaran-ajaran Islam selalu dilakukan dalam bahasa Arab, paling tidak dengan menggunakan huruf Arab. Arabisasi seperti itu tidak lain menempatkan 'keislaman' di Indonesia selalu dalam konteks universal.

Proses seperti ini terus berlanjut - sejalan dengan semakin kuatnya intervensi bahasa Arab ke dalam bahasa-bahasa di Nusantara - , dan pesantren tampaknya hanya melanjutkan proses ini saja. Hal ini mencapai momentumnya ketika pesantren dalam tekanan kekuatan asing, dan ia melakukan gerakan defensif non-kooperatif. Pemasok utama nilai dan pengetahuan yang dapat dipercaya dalam situasi seperti itu adalah Kitab Kuning yang sudah beredar sangat luas di lingkungan mereka. Kalaupun ada pasokan baru - dan ini sangat banyak ketika alumni Timur Tengah kembali ke Indonesia - prosesnya tetap harus mempertimbangkan standar Kitab Kuning yang sudah menyebar itu, kecuali setelah terbukanya kembali hubungan pesantren dengan 'dunia umum', sejak kira-kira tiga dasawarsa yang lalu.

Mas'udi mencoba melihat masalah ini dari sudut lain, yang lebih inherent dalam kehidupan pesantren, yaitu berkaitan dengan pandangan kalangan pesantren mengenai 'ilmu'. Bagi masyarakat pesantren, ilmu adalah sesuatu yang bisa diperoleh melalui jalan pengalihan, pemwarisan, transmisi, bukan sesuatu yang bisa diciptakan, created. Dalam salah satu Kitab Kuning yang menjadi pedoman belajar kalangan pesantren, Ta'lim al Muta'allim Tariq al-Ta'allum, diajarkan bahwa "Ilmu adalah sesuatu yang kamu ambil dari lisan rijal (guru/kyai), karena mereka itu telah menghafal bagian yang paling baik dari yang mereka dengar dan menyampaikan bagian yang paling baik dari yang pernah mereka hafal."

Di kalangan pesantren memang diakui 'cara lain' untuk memperoleh ilmu - jadi tidak hanya dengan cara transmisi seperti itu. Namun demikian, 'cara lain' yang dimaksud bukanlah cara yang lebih rasional (nalar) melainkan cara yang bersifat gaib dalam proses hubungan langsung manusia dengan Yang Maha Berilmu, identik dengan proses pewahyuan. Kalangan pesantren menyebutnya sebagai ilmu ladunni.

Bagi masyarakat pesantren, dengan demikian, ilmu dipandang sebagai sesuatu yang suci, sacred. Tidak boleh spekulatif, akal-akalan. Puncak dari pandangan ini, ilmu dianggap wahyu tersendiri, atau, paling tidak, ia hadir sebagai penjelas wahyu. Seperti halnya wahyu yang hanya bisa 'dimonopoli' oleh Nabi, ilmu juga diyakini hanya bisa dikuasai oleh ilmuwan, ulama. 
Pandangan mereka seperti itu nampaknya dipengaruhi oleh pemahaman mereka terhadap hadits, "al ulama warasat al anbiya".

Dengan pandangan keilmuan yang demikian ketat, tidak dinamis, maka pengajaran dan pendidikan yang berlangsung selalu merupakan pengulangan sebatas 'kata-kata' ulama. Ada dua konsekuensi yang saling terkait karena hal ini:

Pertama, keseragaman akan dengan mudah menjadi ciri yang sangat mencolok. Kalau saja terjadi perbedaan, maka perbedaan itu hampir bisa dipastikan hanya dalam pengungkapannya saja. Kedua, kitab sebagai karya ulama (terdahulu) yang memberikan keterangan langsung terhadap kata-kata wahyu adalah sentral, sedangkan Kyai yang memberikan keterangan atas kitab itu adalah subordinat, atau sekadar alat untuknya (tidak berhak mengevaluasinya).

Dalam jangkauan sejarah yang lebih luas, pendapat van Bruinessen, yang selaras dengan pandangan Mas'udi di atas, tampaknya cukup penting untuk dicatat. Menurutnya Kitab Kuning yang berkembang di Indonesia pada dasarnya merupakan hasil pemikiran ulama abad pertengahan, mulai abad ke-10 M hingga abad ke-15 M. Tradisi keilmuan yang berkembang pada masa-masa itu bertolak dari pandangan keilmuan yang sangat ketat; 'dalam tradisi [intelektual] abad pertengahan, semua ilmu pada dasarnya sudah merupakan sistem pengetahuan yang pasti”. Gagasan untuk menyempurnakan siste ilmu pengetahuan dianggap sesuatu yang menyimpang dan mengaburkan. Van Bruinessen kemudian merujuk pandangan Aziz al-Azmih yang meneliti dasardasar metafisika pemikiran Arab. Ia akhirnya menyimpulkan:

"Jadi, karya mengenai topik apapun hadir dalam tujuh bentuk: kompilasi yang tidak komplit, koreksi atas kesalahan-kesalahan teks, penjelas terhadap masalah yang samar, peringkasan dari teks panjang, pengumpulan teks yang terpisah-pisah, perapihan susunan bahan yang kurang teratur, dan pengambilan/pencuplikan kesimpulan."

Beberapa alasan di atas nampaknya cukup untuk sekadar memahami penempatan Kitab Kuning yang begitu penting di dalam sistem keilmuan pesantren. Namun, bagi sebagian kalangan pesantren sendiri, alasan-alasan seperti itu mungkin akan dianggap kurang idealis. Mungkin juga terkesan bahwa Kitab Kuning dalam konteks perlembangan pemikiran keislaman di Indonesia sejauh alasan-alasan di atas bernilai statis. Bukankah dalam kenyataannya Nusantara/Indonesia adalah wilayah 'pinggiran' dalam peta peradaban Islam, sehingga kehadiran dan perkembangan Kitab Kuning itu sendiri dapat diartikan sebagai faktor dinamis? Paling tidak dalam proses pengayaan pengetahuan ajaran-ajaran Islam, tidakkah Kitab Kuning di pesantren menjadi sangat signifikan? Dalam kaitan ini, Ali Yafie memberikan pandangannya bahwa "Peran kitab tersebut (Kitab Kuning) sebagai salah satu unsur mutlak dari pengajaran/pendidikan pesantren adalah 
sedemikian pentingnya dalam proses terbentuknya kecerdasan intelektualitas dan moralitas kesalehan (kualitas keberagamaan) pada diri peserta didik (thalib/santri).”

Dengan beberapa catatan, Abdurrahman Wahid mempertimbangkan segi dinamis perkembangan Kitab Kuning di pesantren. Menurutnya, Kitab Kuning merupakan faktor penting dalam pembentukan tradisi keilmuan yang fiqh-sufistik yang didukung penguasaan ilmu-ilmu instrumental, termasuk ilmu-ilmu adabnya (humanistik) Tanpa Kitab Kuning, dalam pengertian yang lebih kompleks, tradisi intelektual di Indonesia agaknya tidak akan bisa keluar dari kemelut sufi ekstrim dan fiqh ekstrim. Apa yang dicapai oleh Kyai Ihsan Jampes melalui karya-karyanya, Siraj al Thalibin dan Manahij al Imdad, yang masing-masing merupakan komentar atas Minhaj al Abidin dan Iryad al Ibad, merupakan contoh prestasi intelektual yang mengandalkan Kitab Kuning. "Dalam Manahij al Imdad ini, sekali lagi, terbukti kemampuan ulama di pesantren untuk mengkombinasikan antara kemampuan mendalami ilmu-ilmu agama secara tuntas, di samping mengamalkan tasawwuf secara tuntas pula." Masalahnya mungkin adalah pesantren dituntut untuk melakukan kreasi baru dan mentransformasikan Kitab Kuning sejalan dengan kecenderungan intelektual modern.

Dengan demikian, kita melihat ada dua pandangan mengenai posisi dan signifikansi Kitab Kuning di pesantren. Pertama, dan mungkin yang paling kuat, kebenaran Kitab Kuning bagi kalangan pesantren adalah referensi yang kandungannya sudah tidak perlu dipertanyakan lagi. Kenyataan bahwa Kitab Kuning ditulis sejak lama dan terus dipakai dari masa ke masa menunjukkan bahwa Kitab Kuning sudah teruji kebenarannya dalam sejarah yang panjang. Kitab Kuning dipandang sebagai pemasok teori dan ajaran yang sudah sedemikian rupa dirumuskan oleh ulama-ulama dengan bersandar pada Al Qur'an dan al Hadits.

Menjadikan Kitab Kuning sebagai referensi tidak berarti mengabaikan kedua sumber itu tetapi pada hakekatnya justru mengamalkan ajaran keduanya. Kepercayaan bahwa kedua Kitab itu merupakan wahyu Allah menimbulkan kesan bahwa al-Qur'an dan al-Hadits tidak boleh diperlakukan dan dipahami sembarangan. Cara yang paling aman untuk memahami kedua sumber itu - agar tidak terjerumus dalam kesalahan dan kekeliruan yang dibuatnya sendiri - adalah dengan mempelajari dan mengikuti Kitab Kuning. Sebab kandungan Kitab Kuning merupakan penjelasan dan 'pengejawantahan' yang siap pakai, dan rumusan ketentuan hukum yang bersumber dari al Quran dan al Hadits, yang dipersiapkan oleh para mujtahid di segala bidang.

Pandangan kedua - yang mulai muncul dalam tiga dasawarsa terakhir - adalah bahwa Kitab Kuning penting bagi pesantren untuk memfasilitasi proses pemahaman keagamaan yang mendalam sehingga mampu merumuskan penjelasan yang segar tetapi tidak ahistoris mengenai 
ajaran Islam, al Qur'an dan al Hadits. Kitab Kuning mencerminkan pemikiran keagamaan yang lahir dan berkembang sepanjang sejarah peradaban Islam.

Untuk menjadikan pesantren tetap sebagai pusat kajian keislaman, maka pemeliharaan bahkan pengayaan Kitab Kuning harus tetap menjadi ciri utamanya. Termasuk dalam proses pengayaan itu adalah penanganan Kitab Kuning dalam lapangan dan masa yang luas, termasuk yang lahir belakangan, al kutub al ashriyyah. Hanya dengan penguasaan Kitab Kuning seperti itulah, kreasi pemikiran keislaman yang serius di Indonesia tidak akan berhenti.

Salah satu komponen terpenting pesantren adalah literarur kitab klasik, khususnya karya-karya ulama syafi'iyah. Pengajaran kitab-kitab klasik, atau yang populer dengan nama kitab kuning, merupakan satu-satunya pengajaran formal di pesantren. ${ }^{9}$ Tujuan utama pengajaran ini untuk mencetak kader-kader ulama yang mampu menjawab berbagai persoalan sosial keagamaan ketika kelak terjun ke masyarakat.

Pengajaran kitab kuning juga menjamin kelestarian khasanah intelektual Islam. Melalui pesantren, puluhan, bahkan ratusan kitab kuning dipelajari sebagai salah satu sumber pengetahuan keagamaan. Kitab-kitab tafsir, hadis, fiqh, tasawuf, dan ilmu-ilmu lain hampir tak mungkin dikaji secara mendalam di luar pesantren. Keberadaan dan pengajaran kitab kuning, dengan demikian, menjadi faktor kunci keberlangsungan dan kelestarian tradisi intelektual pesantren.

\section{Kesimpulan}

Kajian di pesantren dalam konteks epistemologi, dengan demikian, sangat bercorak bayani. Pesantren sangat menekankan ketaatan terhadap teks, otoritas kitab kuning. Nalar burhani yang bisa dikembangkan melalui misalnya kajian ushul fiqh dan manthiq kurang mendapat tempat, bahkan hampir tidak ada sama sekali. Keterikatan terhadap apa yang tersurat dalam teks sangat mewarnai kajian keislaman di pesantren.

Nalar irfani cukup berkembang di kalangan pesantren. Kegiatan mujahadah, istighosah, dan dzikir-dzikir lainnya menjadi bagian integral kehidupan pesantren. Pendekatan moral keagamaan melalui pengajaran tasawuf yang bersifat aplikatif menjadi bagian penting penanaman moral santri. Di kalangan pesantren bahkan muncul istilah-istilah ma'rifat, laduni, jadzab, dan lain-lain yang menjadi karakteristik nalar irfani.

Banyak tantangan yang dihadapi pesantren, khususnya terkait dengan pengembangan kajian keilmuan dalam rangka menjawab persoalan-persoalan kontemporer umat Islam di Indonesia. Isu HAM, Gender, dan dan nasionalisme, misalnya, menjadi tantang besar bagi

\footnotetext{
9 Zamakhsyari Dhofier, Tradisi Pesantren, LP3ES, h.50.
} 
kalangan pesantren untuk menjawab dan emmcahkan problem kebangsaan tersebut. Namun, jika pesantren hanya mengandalkan literatur kitab klasik apalagi dengan metodologi pengkajian yang bersifat tradisional sebagaimana yang selama ini dikembangkan, maka persoalan-persoalan di atas tidak terjawab dengan baik.

Kajian keilmuan di pesantren harus lebih memberikan porsi besar bagi pengembangan kajian keislaman dengan corak burhani. Demokrasi hanya bisa tegak dengan berlakunya supremasi hukum. Hukum memiliki logika dan rasionalitas-nya, yang itu bisa dikembangkan dengan mengkaji lebih banyak ushul fiqh dan manthiq.

Dengan mensinergiskan tiga nalar, bayani, burhani, dan irfani, pesantren akan mampu menghadapi tuntutan zaman. Untuk itu, pesantren perlu merumuskan kurikulum kajian keislaman secara lebih serius dan sistematis dengan memeprtimbangkan porsi masing-masing nalar tersebut. Lebih penting lagi adalah mengembangkan metodologi kajian yang juag disesuaikan dengan nalar bayani, nalar burhani, dan nalar irfani secara bersamaan dan bersifat komprehensif.

\section{DAFTAR PUSTAKA}

Adib, Shohibul, DISKURSUS EPISTEMOLOGI BARAT DAN ISLAM (Telaah Signifikansi Filsafat Ilmu terhadap Studi ke-Islaman), majalah Islam Online "Islamuna", Kamis, 18 Maret 2010.

al-Afriqi, Muhammad ibn Mukrim ibn Manzur, Lisan al-'Arab, Juz. XIII (Cet. I; Bairut: Dar Sadir, t.th.).

al-Manawi, Muhammad 'Abd Rauf, al-Tauqif 'ala Muhimmat al-Ta'arif (Cet. I; Bairut: Dar al-Fikr al-Mu'asir, 1410 H.).

Bruinessen $\longrightarrow$ Kitab Kuning, Pesantren dan Tarekat: Tradisi-tradisi Islam di Indonesia, Mizan, Bandung, 1995.

Bruinessen, Martin van, NU: Tradisi, Relasi-relasi Kuasa dan Pencarian Wacana Baru, LKiS, Yogyakarta, 1994.

Dhofier, Zakhsyari, Tradisi Pesantren: Studi tentang Pendangan Hidup Kyai, LP3ES, Jakarta, 1982.

Fanani, Ahmad Zaenal, KRITIK NALAR DALAM STUDI HUKUM ISLAM: SEBUAH PENGANTAR, Makalah, 2006.

Gaffar, Abdul, Epistemologi Bayani, Burhani, Irfani, Media Online Islamic Science

Gaffar, Abdul, Epistemologi Bayani, Burhani, Irfani, Media Online Islamic Science

Gie, The Liang, Pengantar Filsafat Ilmu, The Science and Tecnolody Stues Foundation, Bandung, 1987. 
Hamerma, Harry, Pintu Masuk ke Dunia Filsafat, Kanisisus, Yogyakarta, 1992.

I, n Zakariya Abu al-Husain Ahmad ibn Faris, Maqayis al-Lugah, Juz. I, Bairut: Ittihad al-Kitab al'Arabi, 1423 H./2002 M.

Karel A. Steenbrink, Pesantren, Madrasah, Sekolah, LP3ES, Jakarta, 1986.

Kurdi, Muhammad, Pendekatan Bayani, Burhani dan Irfani dalam Ranah Ijtihadi Muhammadiyah, www.muhammad-kurdi.blogspot.com (Oktober 2008).

Mastuhu, Dinamika Sistem Pendidikan Pesantren: Suatu Kajian tentang Unsur dan Nilai Sistem Pendidikan Pesantren, INIS, Jakarta, 1994.

Rahardjo (ed.), Wahid, Abdurrahman, Bunga Rampai Pesantren, Dharma Bakti, Jakarta, 1995.

Rahardjo , Menggerakkan Tradisi: Esai-esai Pesantren, LKiS, Yogyakarta, 2001.

Rahardjo Pesantren dan Pembaharuan, LP3ES, Jakarta, 1974.

Rahardjo, M. Dawam, Pergulatan Dunia Pesantren: Membangun dari Bawah, P3M, New Jersey, 1985.

Rodric Firth, Encyclopedia International, Gloria Incorperation, Philippenes, 1972.

Saifullah, Ali, Antara Filsafat dan Pendidikan (Surabaya: Usaha Nasional, 1989).

Soleh, A. Khudori, Epistemologi Bayani, www.id.shvoong.com/tags/episemologi-bayani, 07 Maret 2010.

Tafsir, Amad, Filsafat Umum Akal dan Hati Sejak Thales Hingga Capra, Remaja Rosdakarya, Bandung, 2000.

Wahab, Wahib, Rekonstruksi Epistemologi Burhani Penyelarasan Metodologi Dalam Perspektif Al-Jabiri. www.bahrudinonline.netne.net, (23 April 2009).

Zemek, Manfred, Pesantren dalam Perubahan Sosial, P3M, Jakarta, 1986. 